\title{
Power Asymmetry in the Mekong River Basin: The Impact of Hydro-Hegemony on Sharing Transboundary Water
}

\author{
Marlen Rein
}

\begin{abstract}
Does the allocation of transboundary water strengthen cooperation among states or cause international conflicts? This is a question that is highly disputed among several scholars, whereas the arguments of both sides seem equally rational. An analogous dissent can be seen in the research area of the Mekong River. For that reason, it is rational to avoid engaging in this everlasting disagreement and rather look at the problematic question from another viewpoint. This article deals with the Mekong case from a relatively new angle by combining the concepts of power, hydro-hegemony, and coexistence of conflict and cooperation as proposed by the London Water Research Group for analysing the impacts of hydro-hegemony on water allocation. This approach enables us to observe that the power asymmetry deriving from four types of power (geographic, material, bargaining, and ideational power) gives China the position of the hydro-hegemon that is followed by five weaker non-hegemons in the following order: Laos, Thailand, Myanmar, Vietnam, and Cambodia. Despite the great number of collaborative groups, the non-hegemons have not been able to resist the hydro-hegemony of China effectively, as the unity of non-hegemons is mostly hampered by different national interests. Therefore, the bilateral relations of China with the other riparian states individually-especially with Laos and Cambodia-have been stronger than on the multilateral basis with the Mekong River Commission.
\end{abstract}

Keywords: power asymmetry, hydro-hegemony, transboundary water, Mekong River Basin

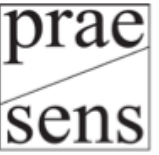

Rein, Marlen. "Power Asymmetry in the Mekong River Basin: The Impact of Hydro-Hegemony on Sharing Transboundary Water." In Vienna Journal of East Asian Studies, Volume 8, eds. Rudiger Frank, Ina Hein, Lukas Pokorny, and Agnes Schick-Chen. Vienna: Praesens Verlag, 2016, pp. 127-162.

https://doi.org/10.2478/vjeas-2016-0005 


\section{Introduction}

Environmental issues constitute a larger proportion of the countries' foreign and security policy than ever before, especially due to the increasing demand on natural resources and human-induced environmental degradation. Whereas scholars mainly started to turn their attention towards the environment as an essential part of international relations paradigms in the 1970s, the studies became more systematic and specific only in the late 1990s. Next to the two popular concepts of 'climate change' and 'sustainability', there is also a growing attention directed towards water. Although we may not notice the seriousness of water scarcity in Europe, it has become a severe concern and even a source of tensions in several parts of the world.

The clashes between Sumerian city-states in 2500 BCE are considered to be the first known conflicts over water use, but the discourse about water conflicts in academia, media, foreign policy, and even culture has become more popular rather recently. For instance, there are numerous articles written about the danger of upcoming water wars, while we celebrate every year the World Water Day and we can even read novels written about fictional water wars (e.g. Memory of Water by Emmi Itäranta). Nevertheless, among scholars a great discrepancy exists about the relationship between conflicts and environment and, more specifically, between conflicts and transboundary water allocation.

Broadly speaking, scholars fall into two antagonistic camps. Whereas one group warns against the possible relationship between environmental problems-including water allocation - and international conflicts, the other side suggests that environmental problems may enhance cooperation between states. Thomas F. Homer-Dixon (2010), one of the most popular scholars in this area, suggests that the connection between environmental scarcity - comprising of supply-induced, demand-induced, or structural scarcities - and violent conflict is rather indirect but still relatively strong and hence cannot be ignored. This means that usually the environmental problems per se do not induce violence, but together with other social, political, or economic difficulties can bring about severe violent conflicts. Peter Gleick from the Pacific Institute (2012) has presented a similarly negative view by proposing a chronology and map of water conflicts. Arun Elhance (1999: 7) as well as Wenche Hauge and Tanja Ellingsen (1998: 314) could likewise be rather categorised under the more pessimistic perspective, as they acknowledge the linkage between environmental problems and conflictive stance.

Alternatively, according to Aaron T. Wolf et al. (2006), water resources offer more incentives for cooperation than for violent conflicts. Also Marit Brochmann and Nils P. Gleditsch (2012) have concluded that solely sharing a river basin does not influence the risk of violent conflict between states, but at the same time they do not deny that the inequality deriving from the location of countries along the river basin - upstream versus downstream - might exacerbate the tensions. Additionally, 
Daniel Deudney (1990) proposes that environment and national security are two separate issues and should not be handled together.

It is thus difficult to find any consensus in this multiplicity of opinions and approaches, as both sides have reasonable arguments. Nevertheless, in many parts of the world, especially in Africa, Middle-East, and Asia, we can see that the allocation of transboundary water is causing severe tensions and hence should be investigated more thoroughly. Whereas most of the transboundary river and lake basins are shared by two countries, there are also those shared by more riparian states. The Mekong River Basin in Southeast Asia is a good example, as it is shared by six states, i.e. Cambodia, China, Laos, Myanmar, Thailand, and Vietnam. Fortunately, violent incidents over water use have been rare in the region, but it is possible to see tensions, accusations, and unilateral actions that threaten the cooperation as well as the environment. Moreover, as there are often serious problems with floods and droughts as well as controversies about the active development of hydropower projects in the region, it offers an interesting case for analysis.

Just as there are contrasting views among scholars about the connection between environmental problems and international conflicts, there are also diverse opinions regarding water allocation in the Mekong River Basin. Scholars such as Dinar et al. (2007), Onishi (2007), and Schmeier (2009) consider water sharing of the Mekong as a good opportunity for inducing collaboration as a spillover effect on other issues in the region. On the other hand, there also exist several pessimistic viewpoints. For instance, Cartin et al. (2012), Collins (2003), Haacke (2013), Hinton (2000), Kirby et al. (2010), Li (2012), and Wolf and Newton (2008) rather emphasise conflictive events and growing tensions over water sharing in the river basin.

This complicated situation of highly diversified perspectives has hence prompted me to examine the Mekong case from a slightly different angle, not focusing solely on the cooperative or conflictive examples but rather combining them. Furthermore, as the riparian states of the Mekong are very different in terms of their material capabilities, political and economic conditions, as well as location and size, I find it interesting to investigate the case with a relatively new and non-traditional approach proposed by the London Water Research Group by adding the dimension of power and hydro-hegemony to the analysis. There have also been earlier attempts of studying the role of power in the environmental issues, but it has not been used very systematically. Nevertheless, DeSombre (1999), Mitchell (2010), and Victor et al. (1998) have linked the issues of power with environment and their main conclusions have been that, due to their better positions, powerful states can force weaker countries to act in a certain way in environmental matters as well.

The main research question of this article is: How does hydro-hegemony influence transboundary water sharing in the Mekong River Basin? In order to answer this question thoroughly two sub-questions for each section are raised. The first step of the analytical framework requires analysing the countries according to the con- 
cept of hydro-hegemony by assessing the power relations between the six riparian states via four different types of power, i.e. the geographical, material, bargaining, and ideational power. Thereby it will be possible to determine the hydro-hegemon and non-hegemons of the river basin and their differences in terms of these forms of power. Although several scholars have already referred to China as the hydrohegemon - and it is obvious that China has a strong position in the region-this paper examines whether China could be seen as the most powerful state in all types of power under consideration and if it also has the supremacy in the question of water-sharing, or whether it has deficiencies in some categories. As the bargaining and ideational are less visible types of power, the content analyses of statements, speeches, and media articles form an essential part of these sections. As the purpose of the article is to understand recent trends, the time period of these two content analyses is $2007-14$.

The second section of the analysis examines whether and which cooperative groups have initiated the weaker countries for resisting the hydro-hegemon, and what could be their strong and weak aspects. In case the non-hegemonic states have been passive in establishing alliances, then it would be interesting to look at the main reasons for their inactiveness. The third segment of the analytical framework enables us to find out which type of interactions are there between the hydrohegemon and non-hegemonic states, and whether the cooperative methods of the non-hegemons have been successful.

This three-level analytical framework allows us to present an extensive overview of the situation in the Mekong Basin, while it does not focus exclusively on one hydro-hegemonic state but also concentrates on the role of non-hegemons and on the general power asymmetry in the basin. It observes thereby the role of hydrohegemonic order in the relations between riparian states and its impact on the actions and behaviour of countries in water-sharing questions.

The article starts with an explanation of the three-level analytical framework whereby I will introduce the approach of the London Water Research Group and the modifications made for this research. Following this, I will apply the analytical framework to the case of the Mekong River Basin by analysing the distribution of four types of power, the main collaborative counter-hegemonic measures, and the relations between the hydro-hegemon and non-hegemons according to the Transboundary Water Interaction Nexus (TWINS) approach. In the final section, I will demonstrate the main conclusions and answer the research questions. I have used variable sources for the analysis, such as academic journals and books for the theoretical part, reports of meetings and media articles for the content analyses, statistics from different databanks, several reports and homepages of the collaborative groups, national laws, strategies and action plans, and international treaties. 


\section{Analytical Framework}

The analytical framework consists of three main categories derived mainly from the London Water Research Group and slightly modified for the purposes of this research. The London Water Research Group is a network of academics dealing predominantly with water research and its key members are Tony Allan, Dave Phillips, Mark Zeitoun, Jeroen Warner, Ana Cascão, Naho Mirumachi, and Mark Mulligan (LWRG 2014). The three main components of their methodologies used in this paper are: the hydro-hegemony that enables us to analyse water-sharing issues in relation to the concepts of power and hegemony; the counter-hegemonic tactics of non-hegemons for improving their situation; and, finally, the unified matrix of conflict and cooperation that allows for analysing the relations between two sides in a multi-layer framework (Cascão and Zeitoun 2010b: 27; Mirumachi and Allan 2007). Although these three approaches are often used separately, they reinforce each other and are therefore applicable for one cohesive research.

As these approaches allow us to include the question of power and hegemony to the transboundary water allocation and also simultaneously investigate conflictive and cooperative events, we are offered with an alternative way to the disputatious theoretical perspectives described in the introduction. This particular approach can hence be located between the two antipodes of the international environmental politics explaining the relationship between water allocation and international relations, because it avoids leaning towards one radical viewpoint (i.e. conflict or cooperation) and rather incorporates elements from both polarised perspectives. Additionally, it also includes some elements and definitions coming from the securitisation theory of the Copenhagen School, e.g. the conflict categories of the TWINS approach.

\section{Hydro-Hegemony and Four Dimensions of Power}

'Power' is a very abstract and ambiguous concept used by scholars widely, starting with the traditional notion of Robert A. Dahl (1957: 202-203) and ending with more contemporary definitions, such as the one offered by Joseph S. Nye (2011: 20-23). Although the definitions often seem, at first glance, quite different, it is possible to see that usually the meaning of having power marks the need to use others as tools for achieving desired outcomes. Consequently, when utilising the core of the aforementioned explanations in the topic under consideration here, we may define power as 'a need for achieving desired outcomes in sharing a transboundary river by influencing other actors, e.g. other riparian states'. However, for examining its impact on the transboundary water allocation, it is essential to have some kind of practical and applicable means for measuring power. Cascão and Zeitoun (2010b) have presented 
an appropriate method for analysing power according to the following four dimensions:

1. Geographical power is clearly visible by looking at the geographical positions of each riparian state - upstream or downstream of a river. Although it gives the upstream country a clear advantage and a possibility to manipulate water flows, the example of Egypt demonstrates that also downstream countries can be very powerful (Cascão and Zeitoun 2010b: 31) and thus it is not the most important indicator. Whereas the location measured only in terms of up- and downstream of a river could be too superficial for understanding the differences among the lower riparian states, I will additionally analyse the vulnerability of each country by looking at the share of the river basin catchment area in their territory and the number of people living in the basin. Hence, if the catchment area comprises a high percentage of the country's territory and a great share of population lives in the basin area, then the state is more vulnerable and affected by the alterations made in the upper part of the basin and has a lower indicator for the geographical power.

2. Material power measures the material capabilities of each riparian state, including economic power, military might, technological prowess, ${ }^{1}$ relative size, and international political and financial support that are used in order to gain the compliance of other parties (Cascão and Zeitoun 2010b: 31; Zeitoun 2008: 26). The subcategories for measuring the material power in this research are: the gross domestic product (GDP) at purchasing power parity (PPP); GDP growth and the number of mainstream hydropower projects already constructed or in progress in the river basin for measuring the economic power; the share of military expenditure as a percentage of GDP; the number of active military personnel and the size of the defence budget of the riparian states for analysing the military power; size of population; adult literacy rate; gross enrolment in tertiary education as a percentage of respective school aged population; life expectancy at birth rate; labour force participation rate; unemployment rate; number of mobile cellular subscriptions and fixed broadband Internet subscribers for measuring the human capital; international support given for water management of the river or to the region (river basin); the renewable water available for analysing the amount of water resources of the states; and the size of the countries.

3. Bargaining power indicates the power of influencing the terms of agreements for getting desired results (Cascão and Zeitoun 2010b: 31). Some common examples of the bargaining power are: finding official recognition through an in-

1 In this paper I have labelled the term more widely by using the category of 'human capital'. 
ternational treaty; claiming the moral high ground by linking the question with international water law; linking water with some other important or emotional issues (issue-linkage); influencing the negotiations by imposing the terms of bilateral agreements; refusing to negotiate and cooperate, or agreeing to negotiate only on its own terms; promoting cooperative institutions and using trade-offs (Cascão and Zeitoun 2010a: 189-190; 2010b: 36; Zeitoun 2008: 26). Since bargaining power is not as clearly visible and measurable as the two first types of power, it is useful to use content analysis of statements of meetings in order to see whether some countries have influenced the course of negotiations by using some of the aforementioned methods. Additionally, I will look at some factors that may influence the bargaining positions, such as the role of investments or hydropower projects.

4. Ideational power is the less visible and the most abstract one among the four different types of power representing 'the capacity of a riparian to impose and legitimise particular ideas and narratives' (Cascão and Zeitoun 2010b: 32, 36). The most common method of this type of power is the usage of sanctioned discourse by delegitimising other types of discourse with its own hegemonic rhetoric, hiding necessary data, sharing ambiguous information, having better knowledge, stalling, securitising, using issue-exclusion and co-opting (Cascão and Zeitoun 2010b: 31, 36; Warner and Zeitoun 2008: 807; Zeitoun 2009: 15; Zeitoun and Allan 2008: 8). The ideational power will be predominantly examined with the content analysis of media, but it is also complemented with the question of data sharing among the riparian states, as the control over hydrological data enables to shape the ideas in the river basin in a desired way. The content analysis examines the following techniques: linking the issue of water allocation to national security and survival; using justifications, threats, and accusations as well as the discourse about data sharing and cooperation. In order to also investigate the hidden techniques, i.e. how the media has created and shaped ideas in a certain manner, the mood and focus of the articles will also be scrutinised.

After examining these four types of power individually, it is possible to determine the hydro-hegemonic situation of each riparian state and the power asymmetry in the Mekong River Basin. Unlike Cascão and Zeitoun (2010b: 32) I will use numerical scales (1-6) for demonstrating the strength of each type of power for each country in order to have a better and easily comparable overview. Six points correspond thereby to the highest possible score and one to the lowest measure. After allocating the values of each type of power to every riparian state, it is possible to determine the hydro-hegemon and the non-hegemons of the river basin and the reasons for this result. 
In this paper I use the definition of hydro-hegemony as proposed by Ana Elisa Cascão and Mark Zeitoun (2010b: 27-28) who have modified the traditional concept of hegemony proposed by Antonio Gramsci. According to their definition, 'hydrohegemony is hegemony at the river basin level that occurs where control over transboundary flows is consolidated by the more powerful actor', referring to the situation where 'the first amongst equals', i.e. the most powerful actor from a group of formally equal parties, has the controlling position due to the four forms of power (Warner and Zeitoun 2008: 805). The first section thus enables to answer the following first two sub-questions:

(1) How are the four types of power, i.e. geographical, material, bargaining, and ideational power, distributed between the six riparian states of the Mekong River Basin?

(2) Which riparian state has the most and which ones have less powerful positions according to these types of power, i.e. which state can be considered as the hydro-hegemon and which ones are the nonhegemons of the river basin?

Whereas several scholars have already referred to China as the hydro-hegemon (e.g. Menniken 2007; Sinha 2012; Chellaney 2013), the second sub-question seems to have an obvious answer. Nevertheless, as my purpose is to examine the power relations between all riparian states by also looking at the differences between the non-hegemons and the reasons for this kind of situation - and not solely focusing on a simple division between one hegemonic state and five non-hegemons-it is reasonable to use this type of question for comparing the countries. Additionally, as the analytical framework of this paper includes several types of power that could give variable results, it would be interesting to observe whether China has some weak aspects or could be seen as the strongest riparian state in every aspect.

\section{Counter-Hegemonic Tactics}

The second part of the analysis is dedicated to the counter-hegemonic tactics implemented by the non-hegemons for examining whether the weaker states of the Mekong River Basin have also tried to improve their situation and balance the asymmetrical condition by means of cooperation among each other or with some third parties. Although there are several options for applying counter-hegemonic tactics (as proposed by Cascão 2006: 5; Daoudy 2009; Warner and Zawahri 2012: 219, 222), I will only focus on the cooperative measures of the non-hegemons, i.e. on the formation of several blocks, such as the Mekong River Commission, the Greater Mekong Subregion Program, ASEAN Mekong Basin Development Cooperation, 
and many other groups in order to see whether the weaker states have been able to overcome their modest situation together. I will therefore investigate main activities and interest areas, regularity of meetings, attitude against the hydro-hegemon, and other strong and weak points of the groups. This section thus seeks to answer the following questions:

(1) Whether and which cooperative methods have the non-hegemonic states used in order to resist the hydro-hegemon? What are their strong and weak points?

(2) If the countries have not used many cooperative methods, what could be the reason for this passiveness?

\section{Transboundary Water Interaction Nexus}

The third and final part of the analytical framework uses the Transboundary Water Interaction Nexus proposed by Naho Mirumachi and John Anthony Allan (2007). It is a useful two-dimensional method that neglects the typical linear continuum of conflict and cooperation. The model shows that conflictive and cooperative aspects may coexist and do not exclude each other, since conflictive interaction may also include positive effects and every cooperative relation need not be entirely positive (Cascão and Zeitoun 2010b: 29). Whereas the TWINS method requires also information from the two previous sections - e.g. cooperative methods or information about power asymmetry - it is suitable to use it as a final step of the analysis. The model has two parts: the horizontal scale for measuring the cooperation intensity, and the vertical scale for conflict intensity that is mainly adopted from the securitisation theory of the Copenhagen School (Table 1).

The table indicates that the intensities of cooperation and conflict increase downwards, whereas the most positive solution in the cooperative level would be the fifth option and in the conflictive level the first solution. The vertical scale of the model is mainly adopted from the Copenhagen School and adapted to the TWINS model with some small modifications. An important concept among the scale is the 'existential threat' that is used by a securitising actor for changing an issue from a lower level of conflict to a securitised one (Buzan et al. 1998: 24). Nevertheless, the securitisation does not necessarily mean that an actual threat exists but rather that the issue is framed in this manner (ibid.). For instance, Cambodian media has often used securitisation technique by emphasising the threat of the hydropower projects to the fisheries, people, or to the whole country. 
Table 1 Categories of the horizontal and vertical scales of the TWINS model from low to high levels

\begin{tabular}{|c|c|c|}
\hline & Horizontal scale of cooperation intensity & Vertical scale of conflict intensity \\
\hline & $\begin{array}{l}\text { confrontation of the issue - the problem is } \\
\text { acknowledged, but there exists neither joint } \\
\text { action, identification nor shared goals }\end{array}$ & $\begin{array}{l}\text { (1) non-politicisation - the state is not } \\
\text { concerned over the water-sharing issue and } \\
\text { the question is not in the public domain }\end{array}$ \\
\hline (2) & $\begin{array}{l}\text { ad hoc interaction - joint action but no } \\
\text { shared goals }\end{array}$ & $\begin{array}{l}\text { politicisation - water sharing gains a place } \\
\text { on the political agenda and public policy, } \\
\text { requires government decisions and resource } \\
\text { allocations or some other communal gov- } \\
\text { ernance }\end{array}$ \\
\hline (3) & $\begin{array}{l}\text { technical cooperation - shared goals but } \\
\text { no joint action }\end{array}$ & $\begin{array}{l}\text { (3) securitisation-opportunitisation - (a) the } \\
\text { issue is presented as an existential threat } \\
\text { that requires emergency measures and justi- } \\
\text { fies actions outside the normal bounds of } \\
\text { political procedure or (b) the issue offers a } \\
\text { chance to improve the situation by justify- } \\
\text { ing actions outside the normal bounds of } \\
\text { political procedure }\end{array}$ \\
\hline (4) & $\begin{array}{l}\text { risk-averting cooperation - shared goals, } \\
\text { joint action, and a mutual belief that the } \\
\text { other will act as expected, but the states do } \\
\text { not undertake the unforeseen costs in the } \\
\text { future when committing such action }\end{array}$ & $\begin{array}{l}\text { (4) violisation - the issue is intensified to the } \\
\text { point that violent action is employed and } \\
\text { extreme measures are included }\end{array}$ \\
\hline$(5)$ & $\begin{array}{l}\text { risk-taking cooperation - ideal form of } \\
\text { cooperation where costs and risks are taken } \\
\text { into account and the reciprocal behaviour is } \\
\text { evident }\end{array}$ & \\
\hline
\end{tabular}

Own compilation, based on: Buzan et al. 1998: 23-24; Mirumachi and Allan 2007: 5-7; Zeitoun 2007: 219

Whereas the concepts of 'securitisation' and 'existential threat' can be used in numerous ways, unlike the Copenhagen School, I consider any discourse of a state (political leaders, government etc.), media, or other actors in the context of water allocation that includes references to a damaging effect on state, people, animals, biodiversity, water resources, environment, economy, or other similar essential subjects as a securitising action and the aforementioned examples of negative impacts as existential threats. On the other hand, when there exists no direct reference to the damaging effects on these matters but the regulation on the political levele.g. in the national strategies or legislation - is implemented or required, it can be seen as a way of politicisation of water issues. Moreover, the London Water Research Group has also added the concept of 'opportunitisation' referring to a chance 
of improving the current situation by justifying actions outside the normal bounds of political procedure (Mirumachi and Allan 2007: 6). The latter is hence a more positive side of the securitisation. There is also a possibility of desecuritisation, which refers to the situation where an issue moves out from the securitised atmosphere and back into the logic of politics (Buzan and Hansen 2009: 216-217).

Instead of focusing on changes over a certain period of time as it is often done with the model, I will concentrate on the current stance and will not divide the analysis between different time frames. However, I will apply the model for analysing the relationships between multiple actors and not only between two partners as proposed by Mirumachi and Allan (2007). Therefore, I will assess the current bilateral relations between six riparian states, i.e. between the hydro-hegemon and nonhegemons, but also between the hegemon and the bloc of non-hegemons in order to see whether the counter-hegemonic tactics have improved their situation. Thereafter, it is possible to conclude whether the interaction between states is positive, neutral, or negative depending on the values of the matrix (Zeitoun and Mirumachi 2008: 310). The final section of the analytical framework will thus enable us to answer the following two questions:

(1) Which types of interactions (i.e. positive, negative, or neutral) exist between the hydro-hegemon and the non-hegemonic states of the Mekong River Basin according to the TWINS model?

(2) Have the cooperative methods of the non-hegemons (if any) been successful?

\section{Mekong River Basin}

With its strategic location and size, the Mekong River is a highly relevant water source of the region for transportation, fishery, agriculture, industries, public water supply systems, mineral resources, and hydroelectricity (UNEP 2006: 25). At the same time, there is an array of contrasting issues about the Mekong River Basin that make the water management and allocation complicated.

On the one hand, there are already serious differences due to the geographical characteristics of the river basin. As the river extends from the Tibetan Plateau to the Mekong Delta in Vietnam we can see a variable climate ranging from cooler temperate areas to tropical regions. Furthermore, there are great differences due to the monsoon seasons that divide the year roughly into wet (June-October) and dry periods (November-May) (Kirby et al. 2010: 573; MRC 2013a: 5). The Mekong River Basin can also be divided into several smaller sub-basins formed by a great number of tributaries and into six different bio-geographical zones (UNEP 2006: 17-18). This means that the river basin, due to its mountainous features, includes 
areas that are sparsely inhabited as well as regions with many forests, lowlands, and coastal zones.

Next to the geographical differences it is also possible to notice contrasting interests among the riparian states. One of the main disputable areas is the development of hydropower projects that is causing several tensions between the riparian states. For instance, some countries like China and Laos are actively trying to build several hydropower projects in order to produce needful electricity, but they are confronted with the concerns of the downstream states over the dangerous consequences that could possibly emerge due to the constructions at the upstream of the river.

\section{Hydro-Hegemony: Distribution of Power in the Mekong River Basin}

\section{Geographical Power}

Geographical power, as the first type under analysis, is measured with the geographical location but also with the indicators showing the vulnerability of the states. China that enjoys the strategically most convenient location in the upstream of the river basin has the greatest source of geographical power. Also, Myanmar, which is often considered to be a part of the Upper Mekong River Basin (UNEP 2006: 11), has a relatively good position. Nevertheless, as the Mekong River comprises only a narrow and quite inaccessible area of Myanmar, the country is not very interested in engaging in the river management (Schmeier 2009: 33; Thim 2010: 58-60). The feature of vulnerability strengthens the dominant positions of the two upstream states further, as the catchment area comprises 38 per cent of China's territory and only 4 per cent of Myanmar's territory (Thim 2010: 58). Similarly, the percentage of the population living in the basin is low, since the upper reaches are mountainous and sparsely inhabited. Whereas the predominant positions of China and Myanmar in the first type of power are clear, the distribution of geographical power between the other four downstream states may not be that visible and requires the examination of the vulnerability factor.

When considering only the geographical position, Laos and Thailand would have remarkably better positions than Cambodia and Vietnam. However, the indicators for the vulnerability slightly alter the situation. On the one hand, Laos and Cambodia are, according to the selected criteria of vulnerability, clearly more dependent on the river resources than Thailand and Vietnam, because the indicators of catchment area of the countries and the percentage of population living within the Mekong River Basin are higher for Laos and Cambodia. For instance, the catchment area comprises 97 per cent of the territory of Laos and 86 per cent of Cambodia, while 89 per cent of the Laotians and 81 per cent of the Cambodians live within the river basin (MRC 2011b: 13; Thim 2010: 58). On the other hand, Thailand, which is 
situated between Laos and Cambodia, is in a less vulnerable position, as the catchment area comprises 36 per cent of the country while 36 per cent of the Thai population live in the basin (MRC 2011b: 13; Thim 2010: 58). In contrast, Vietnam, having the most inconvenient geographical position in the lower part of the Mekong River Basin, has clearly lower indicators for the vulnerability than Cambodia or Laos, i.e. the catchment area of the basin covers 20 per cent of the country's territory and about 24 per cent of the population live in the basin (MRC 2011b: 13; Thim 2010: 58). These data reassure that even though and due to its location Vietnam has the weakest position in regard to the entire geographical power, the differences between Vietnam and other downstream states - especially Cambodia — are not that great, as the dependency factor has evened out the results.

In brief, the final distribution of geographical power (Figure 1) considering both the location and vulnerability indicates that China has the most powerful position in the basin, followed by Myanmar. Although Laos should, according to its location, have stronger geographical power than Thailand, Lao's remarkably higher levels of vulnerability decrease its relative geographical power, and therefore both countries have an equal position. Cambodia and Vietnam are the weakest countries according to this type of power. Although Cambodia has a larger share of catchment area in its territory and more people living in the basin, Vietnam is still the lowest riparian state depending to a great extent on the activities in the upstream and hence has the weakest position in the geographical power.

\section{Material Power}

The category of material power is relatively wide encompassing numerous subcategories and should therefore offer a comprehensive overview. Firstly, when looking at the economic power as one subcategory of material power, one sees that China enjoys the predominant position among the riparian states due to good values concerning the indicators GDP at PPP, GDP growth, and number of hydropower projects in the mainstream of the river, i.e. seven operational dams, five under construction and sixteen in the planning or preparation stage (International Rivers 2013).

Secondly, it is interesting to notice that, according to GDP values, the other five countries are in quite an equal position, but when adding also the criterion of planned or constructed hydropower projects, the results turn out to be different. This means that despite its low GDP value, Laos has a relatively good power position, as it has been actively developing several mainstream hydropower projects. For instance, among the five downstream states, only Laos has one mainstream dam under construction and additional nine in planning or preparation stage (ICEM 2010: 150). Thailand and Cambodia, on the other hand, are in central positions (both have two mainstream projects in the planning or preparation stage) and the least powerful 
positions belong to Vietnam and Myanmar due to their modest indicators on GDP growth and because of non-existing mainstream hydropower projects. In brief, Laos can be considered as the greatest surprise for the criterion of economic power, as it has compensated its low economic position with the active development of the mainstream hydropower projects.

Military might, as the second subcategory of economic power, is analysed based on three operational criteria, i.e. defence budget, military expenditure as a percentage of GDP, and active military personnel. According to the first sub-criterion, China with the highest defence budget (129.4 billion USD in 2014) is clearly in a predominant position (IISS 2015). The same can be said about the number of China's active military personnel that reaches up to 2.3 million (IISS 2015). The criterion of military expenditure as a percentage of GDP, however, gives quite different results and locates Myanmar, with 4.3 per cent, at the first place (SIPRI 2014). Nevertheless, China enjoys the strongest position of military might and is followed by Myanmar, Vietnam, Thailand, and Cambodia. Laos as a country with lowest scores for all three indicators is hence in the last position.

The results of the analysis of the human capital - with eight operational subcriteria - are diverse and fascinating. This category has also allowed for the changing of the typical ranking and locates Thailand at the most powerful position with its good results of population size, educational and health indicators, unemployment rate, mobile and Internet subscriptions (ADB 2013; UN 2012; World Bank 2012a, 2012b, 2012c, 2012d, 2012e, 2013). China holds the second position due to lower labour force participation, higher unemployment rate, and lower number of mobile cellular subscriptions. Vietnam has quite a similar position as China, as it has relatively average scores in all categories, but also has the highest number of mobile subscriptions. The fourth place in the ranking belongs to Cambodia that has the best indicator on labour force participation but also strong positions in unemployment rate and mobile subscriptions. Thereafter follow Laos and Myanmar that have visibly weaker results.

The next subcategory, which compares the size of the countries' land areas, shows that China again has a clear advantage with its territory totalling 9,388,211 $\mathrm{km}^{2}$ (World Bank 2014). It is followed by Myanmar $\left(653,290 \mathrm{~km}^{2}\right)$, Thailand $\left(510,890 \mathrm{~km}^{2}\right)$, Vietnam $\left(310,070 \mathrm{~km}^{2}\right)$, and Laos $\left(230,800 \mathrm{~km}^{2}\right)$. Cambodia, with $176,520 \mathrm{~km}^{2}$, is the smallest country and hence has the lowest position in this ranking.

Water resources, as the next subcategory of material power, change the power positions once again. Firstly, China with the highest indicator on total renewable water resources of $2011\left(2,840 \mathrm{~km}^{3}\right.$ of total renewable water per year) (Aquastat 2012) has the best position and is followed by Myanmar $\left(1,168 \mathrm{~km}^{3}\right)$, Vietnam $\left(884.1 \mathrm{~km}^{3}\right)$, Cambodia $\left(476.1 \mathrm{~km}^{3}\right)$, Thailand $\left(438.6 \mathrm{~km}^{3}\right)$, and Laos $\left(333.5 \mathrm{~km}^{3}\right)$. Nevertheless, when considering the total renewable water available per capita, the 
situation is quite the opposite, as Laos has the highest indicator $\left(52,322 \mathrm{~m}^{3}\right)$ and China the lowest $\left(2,051 \mathrm{~m}^{3}\right)$ (Aquastat 2012). Cambodia has a better position in this ranking as well $\left(32,884 \mathrm{~m}^{3}\right)$ and is followed by Myanmar $\left(23,972 \mathrm{~m}^{3}\right)$, Vietnam $\left(9,853 \mathrm{~m}^{3}\right)$, and Thailand $\left(6,275 \mathrm{~m}^{3}\right)$. Also, the results of water stress (Gassert et al. 2013) give Laos the best position among the riparian states, followed by Myanmar, Cambodia, Vietnam, Thailand, and China. Therefore, Laos and Myanmar have the strongest positions and China with Thailand the least convenient conditions in this category.

The criterion of international support indicates that the greatest international aid is addressed to the lower riparian countries, deriving, for instance, from Japan, the USA, New Zealand, Germany, and the European Union, whereas Laos and Cambodia are the biggest recipients of foreign aid. Also, Keskinen et al. (2008: 97) and Leibo (2012: 58, 185) suggest that Cambodia is one of the world's most aiddependent countries, as about half of the country's operating budget derives from foreign aid, while Laos has also received substantial foreign investment for its hydropower projects. On the other hand, China, Thailand, and Vietnam receive less international aid and rather invest in the hydropower projects of other riparian states.

When adding all the six subcategories of material power together, it is evident that China enjoys a predominant position. However, as China does not have for each type of power the strongest position, the distance between China and other states is not as great as one would predict. Hence, Laos could be located in the second position, which is actually surprising, as it has low results in the military might and human capital. However, the strong position in water resources and international support secures for Laos a relatively good position of power. Thailand, Myanmar, and Vietnam are equally located in the middle position, while Cambodia with its modest results almost in all subcategories has the weakest position.

\section{Bargaining Power}

Bargaining power, as the third category, is mainly investigated through a content analysis of statements and thereafter supplemented with some more general information about bargaining positions. The content analysis of 60 speeches or statements - 10 from each state from the 2007-13 period - demonstrates that China uses this type of power more actively than the other five riparian countries. However, Myanmar, Vietnam, and Laos also hold quite powerful positions, while Cambodia and Thailand have been more passive.

China has used six different methods in its statements. The most frequent tool used by both China and all the other riparian states has been the verbal promotion of cooperation. One significant example can be seen at the 16th dialogue meeting of the Mekong River Commission (MRC) (2011c: 52), where China used the slogan of 
'Together we can', implying how important it is for China to demonstrate its willingness to cooperate. Additionally, China has often used issue-linkage by relating the question of water sharing with social and general development, traditions, poverty or business, while it has often promoted bilateral agreements and demonstrated its refusal to join the MRC. It is thereby possible to notice how China has imposed its own terms of negotiations by either stating that it wishes to remain a dialogue partner on a bilateral basis or by referring to its power to decide how and when to share necessary data with lower riparian states. It is also clearly visible how China tries to justify its hydropower development by stating that the projects do not affect downstream states negatively.

Myanmar has also promoted cooperation. Interestingly, Myanmar has chosen to emphasise the concept of MRC +2 by referring to the country's wish to remain a dialogue partner and not become a full member. This means that the method of agreeing to negotiate only on its own terms is clearly visible in the official speeches. Myanmar has also used issue-linkage and has demonstrated its importance and success in the dimension material power-for example by emphasising its abundant land and water resources - in order to gather more decision power and a better position in the negotiations. On the other hand, Vietnam has several times made references to the 1995 Agreement and once to international law as well. However, the most popular methods have been the promotion of cooperation and issuelinkage. Additionally, Vietnam has tried to portray itself as a victim in the basin. For instance, it has stated the following: 'In this dry season, Vietnam and its Mekong Delta in particular are suffering from the dual impacts of the most serious ever droughts' (MRC 2010).

Similarly to Vietnam, Laos has referred to the 1995 Agreement of the MRC as a way of finding official recognition through an international treaty, but it has also several times used issue-linkage and promoted cooperation with different partners, e.g. China, Myanmar, ASEAN, Japan, India, the USA, Russia, and the European Union. Due to Vietnam's need to develop hydropower projects, it is also possible to notice several attempts to present the controversial dams in a positive light. In comparison with other states, Cambodia and Thailand have used less methods of bargaining power. The most common tools used by both countries are the promotion of further cooperation and issue-linkage.

When looking at the bargaining strategies as a whole, it is possible to see that the non-membership of China and Myanmar in the Mekong River Commission is an essential and significant factor influencing interactions in the river basin. Their refusals to join the group as full members denotes their high bargaining power, as they have denied negotiating on an equal basis and prefer to discuss the issues in a way that is suitable for them. Additionally, the development of hydropower projects influences their bargaining power. For instance, China and Laos, as the two states with numerous mainstream projects or plans, could be considered as endowed with 
greater bargaining power, because they have been able to disregard the complaints of others over the negative impacts of dams, refuse to negotiate on those issues, discuss the topic on their own terms, or make decisions unilaterally. A good example of China's unilateral action is the construction of the Danwan dam in the mainstream of the Mekong without prior consultation with the downstream states (Keskinen et al. 2008: 93). Another significant factor is the investment in other riparian states. As China, Thailand, and Vietnam are the greatest investors of hydropower projects in other countries, they also have significant power over others. On the other hand, as they are interested in investing in those countries and do not want to lose their potential benefits, they have to be careful and act in a relatively friendly manner so that these countries would not choose other investors. Thus, mutual dominance and interdependency are more than visible.

In a nutshell, China enjoys the strongest position in regard to bargaining power mainly due to several hydropower projects, unilateral actions, its role as an investor, and because of the bargaining techniques used in its official discourse. Vietnam, Laos, and Thailand are equally located in following positions. The main reasons for Vietnam's good placement are its investments in other states and bargaining techniques used at the meetings. The strength of Laos lies in its development of hydropower projects and usage of several bargaining methods. The main reasons for Thailand's good position are its investments but also the planned mainstream hydropower projects and bargaining techniques used in statements. Finally, Myanmar and Cambodia are the weakest states. Myanmar's weakness lies in the fact that it is not a great investor, has no hydropower projects, and seems to display quite a low interest in the river basin. Although Cambodia has used less bargaining techniques than other states, it has only two mainstream dams in the planning stage and is highly dependent on foreign investments - especially on China's finances. Cambodia holds, due to the on-going hydropower development, a similar position as Myanmar.

\section{Ideational Power}

Ideational power is the most abstract and least visible form of the four types of power. Similarly to bargaining power, it is examined in two ways. Firstly, I use content analysis of 300 media articles written about the Mekong River Basin-50 for each country from the 2008-14 period. Secondly, it is supplemented with the overview of the availability of data, i.e. the knowledge about the basin and the openness and willingness to share accurate data with other riparian states.

The results of the content analysis indicate that the tools of ideational power are widely used in all six states but not in the same manner. Interestingly, Thailand has used these tools more often than other states. Firstly, it could be explained by the country's interest in Laos' hydropower projects. On the other hand, the best position 
in press freedom index among the six states (Reporters Without Borders 2014) may contribute to this result as well. For instance, it is often possible to notice that negative impacts and positive effects are handled simultaneously in one article. In addition, the activeness of civil society in Thailand could be seen as an essential factor (Cronin and Hamlin 2012: 26-27). Myanmar, on the other hand, has used less methods of ideational power than other states, which can be mainly explained by the country's little interest in the river basin. Cambodia and Vietnam have used the methods quite actively but China and Laos rather moderately.

The usage of different tools of ideational power can also be linked to the main interests of the countries. For instance, Cambodia has used securitisation most often, which can be explained by its dire situation and the need to show the country's poor living conditions. Cambodian media have thus: highlighted the number of people who are dependent on the river and whose livelihood is threatened by dams; talked about the danger to fishery, food security, biodiversity and animal species; and demonstrated emotional aspects by using interviews with local people. One expressive example of emphasising the emotional factor is the following: "When I heard about this, I panicked. I thought about my family's future... We depend on fishing and the river, the river is our life' (David 2013). Also Vietnam and Thailand have relatively often used securitisation, but China, Laos, and Myanmar have used it very rarely, as two of them are keenly interested in developing the hydropower projects and do not want to link the question of the Mekong with security issues. Therefore, China and Laos rather 'desecuritise' the issue by understating the negative impacts of hydropower development.

There are also great differences in how accusations are used. Thailand is again the most active user of the method. Cambodia, Vietnam, and Myanmar have also used accusations quite often, while China and Laos rarely. On the other hand, Laos and China use justifications repeatedly. They have demonstrated that the projects are not harmful and offer many benefits. The discourse about data sharing is used by all six states in an equally modest manner. Although the promotion of cooperation is the most common tool by all countries, it is used with diverse sanctioned discourse. The members of the MRC have often emphasised the cooperation within the MRC, but China and Myanmar have rather talked about bilateral cooperation or collaboration in other areas. The tool of threatening is used relatively rarely and not very boldly.

The mood of articles demonstrates that the media in Laos, Myanmar, China, and Vietnam publish clearly more articles with positive attitude than in Cambodia and Thailand. The result of Cambodia is expectable, as the country has often tried to show its vulnerability and pessimistic stance. Thai media have used both types of articles moderately, which supports once more the fact that it has often reflected viewpoints from both sides. Also the emphasis of the articles indicates that Cambodia has typically focused on other countries - e.g. the negative impacts of upstream 
projects - and less on its own activities. On the other hand, China, Myanmar, Vietnam, and Laos have mostly focused on the cooperation with and less on the actions of the other riparian states. Thailand has similarly often concentrated on the interbasin cooperation, but also on other countries or mistakes made in the basin.

The next big category under the ideational power looks at the availability of hydrological data. First of all, the control over information is closely linked to the geographical position, as upstream countries have better opportunities to measure and predict necessary hydrological information. This means that China has a clear advantage in this as it has the ability to act unilaterally and keep the necessary data obscure. Several scholars have also accused China of refusing to share necessary data, e.g. Aiken (2014), Chomchai (2005: 144), Cronin (2013: 32), Cronin and Hamlin (2010: 15, 29; 2012: 6, 40), Magee (2013), and Pomeranz (2013: 4). The results of the content analysis indicate that the problem of data sharing is acute among the riparian states. Cronin and Hamlin (2010: 15) suggest that sharing data among the downstream countries is equally flawed, as the states do not give sufficient information to each other. They have especially referred to Laos' secrecy in developing its hydropower projects.

However, there have also been some improvements in data sharing. For instance, China informed other riparian states about 'daily data collections and river monitoring of water levels, rainfall and discharge data for two stations in China' for the first time during the dry season in 2010, and extended the period of data-sharing by 30 days and promised to do it more regularly in 2013 (MRC 2011a: 38; 2013b). Also, the system of Notification, Prior Consultation and Agreement of the MRC may be seen as an improvement in this area. On the other hand, the latter is not entirely functioning and has prompted several misunderstandings and delays. For instance, there have been disagreements about whether Laos' Don Sahong dam is a mainstream one or not. Whereas Laos has stated that it is not a mainstream project and used the system of prior notification, other states claim that it is a mainstream dam that needs prior consultation (Fawthrop 2013). Also Laos' Xayaburi dam has caused strong controversies, as the country has provided information about the dam too slowly and late, not providing sufficient time for a constructive feedback from other countries (Cronin and Hamlin 2012: 74). Therefore, we can see that China as an upstream country has a clear predominant position, but also Laos has the possibility to stall, hide, or share ambiguous information about its own projects.

The combined results of the ideational power demonstrate that China and Laos have the strongest positions in this category. They are followed by Thailand that has been the most active country according to the content analysis. Cambodia, Vietnam, and Myanmar are thereafter in relatively equal positions due to their opportunities in data sharing. The results also indicate that the ideational power is quite evenly distributed among the states, as this type of power also gives the downstream countries more opportunities. However, the factor of data sharing still hinders the per- 
spectives of downstream states greatly, while China as the most upstream country has the most convenient position for deciding how and when to share hydrological data with others. Additionally, Laos, as an active developer of hydropower projects, has with its non-transparent actions and secrecy gathered a powerful position.

\section{Hydro-Hegemon and Non-Hegemons of the Mekong River Basin}

Figure 1, showing the computed average sum of subjectively allocated scores of the four types of power derived from previous information, allows us to explain the power asymmetry and to decide which country is the hydro-hegemon and which are the non-hegemons in the Mekong River Basin. The numerical scale from ' 1 ' to ' 6 ' measuring the geographical, material, bargaining, and ideational power ensures a clearly visible comparison between the six states and enables to comprehend the differences in the strength of each type of power quicker and better than without the numerical scores. Awarding the points is definitely a highly subjective processespecially when considering the last two types of power, i.e. bargaining and ideational - but as the points are derived from many different operational sub-criteria explained beforehand-including much statistical information-the final results demonstrating the average amounts should indicate the highest possible grade of objectivity.

First of all, the final scores demonstrate that, with 6 points, China can be seen as the hydro-hegemon. Although China has in some subcategories - e.g. human capital, water resources and international support of the material power, and in the content analysis of the ideational power-lower scores, overall it still enjoys the most powerful position. Laos with the score of 4 is situated in the second place and has thereby clearly compensated its weakness in the first two categories of power with its bargaining and ideational power. Thailand is situated in the middle position with the score of 3.5, as it has rather decent results in every category. Myanmar with 3 points has also a relatively strong position, despite of its quite low interest in the basin. Vietnam with the score of 2.75 and Cambodia with 2.25 are the two most vulnerable states in the basin. Nevertheless, due to their good indicators on the bargaining and ideational power, they are quite close to other lower riparian states and there is not such a great gap in the power relations as one would predict based on the results of the first two types of power.

The results also indicate that the often emphasised geographical position along the river or the military and economic power alone do not designate the power relations. Although China as the hydro-hegemon in the river basin has also the best position according to geographical and material power, the lower riparian states have compensated their weaker positions in geographical or material power with other means. For instance, Cambodia, Laos, Thailand, and Vietnam have, as a sum 
of all four types of power, better positions contrary to what would be the case when considering only the geographical location. On the other hand, Myanmar has remarkably lost its position in the two latter types of power.

Figure 1 Distribution of power in the Mekong River Basin (compiled by the author)

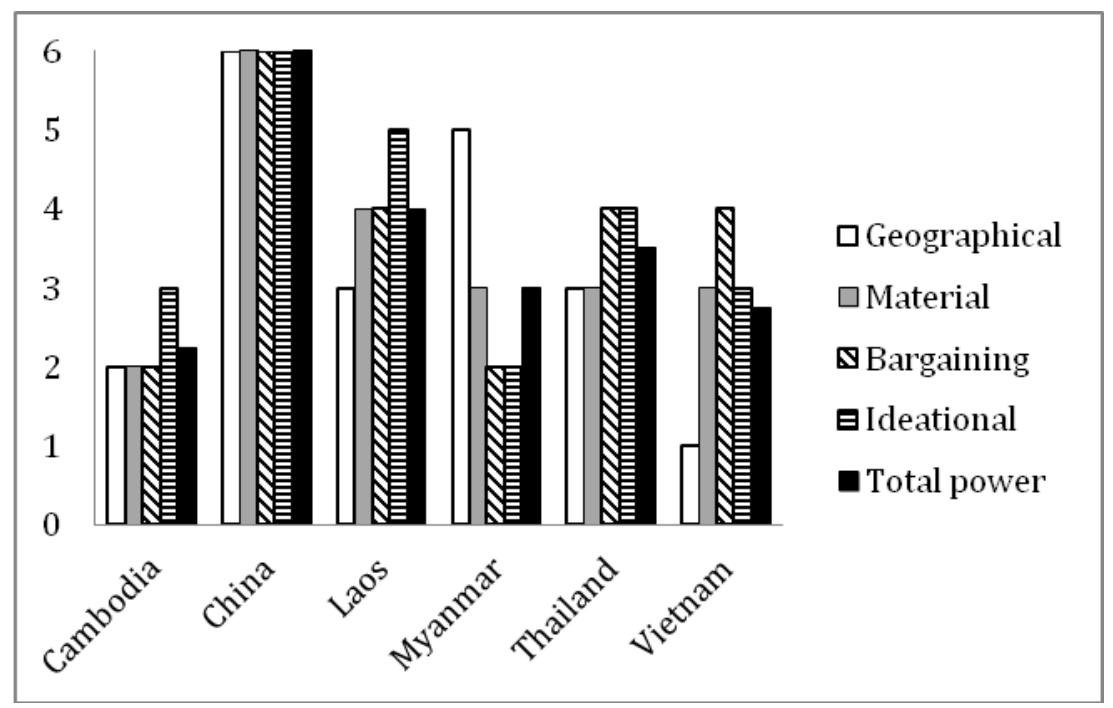

\section{Cooperative Counter-Hegemonic Tactics in the Mekong River Basin}

The power asymmetry in the Mekong River Basin demonstrates that the nonhegemons are in relatively equal positions and thus it should be logical and comparatively easy for them to establish cooperative institutions as a counter-mechanism against China's hydro-hegemony. The analysis of cooperative groups, however, proves the opposite, as the weaker riparian states have not been able to cooperate effectively. The key groups that are analysed are the following: the Mekong River Commission, the Greater Mekong Subregion (GMS) Program, ASEAN Mekong Basin Development Cooperation (AMBDC), Japan's Mekong Initiative, Lower Mekong Initiative (LMI), Mekong-ROK (South Korea) Cooperation, MekongGanga Cooperation, Ayeyawady-Chao Phraya-Mekong Economic Cooperation. Attention is also paid to other smaller groups in the region.

There are several factors that impede the groups to become stronger and more effective in resisting China's hydro-hegemony. One important weak point that all groups share is the infrequency of meetings, as they averagely come together once a year. For instance, the Council of the MRC usually has sessions at least once a year and the Joint Committee twice a year (MRC 1995: Art. 17; 23). Another common 
impediment is the absence of strict regulations that would oblige the member countries to work more actively and steadily. The Mekong River Commission is regulated more strongly than others but still has several weak and loose characteristics that allow the member countries to circumvent the rules by interpreting the regulations differently. In addition, the legally non-binding decisions, high dependency on foreign funding, and a lack of well-functioning dispute resolution (Schulze and Schmeier 2012: 238-239) weaken the organisation. For instance, only 1.2 million USD from the total income of 2.7 million USD of the 2012 budget derive from the riparian governments (MRC 2012).

The great number of different interest areas of the collaborative groups may also hamper focusing on a specific issue and handle the problems quickly. This also means that the main topics are dealt with by many different programs. For instance, human resources development and tourism are the key focus areas of eight different groups; agriculture is handled by seven; transport and trade by six different organisations. Water issues are explicitly included and highlighted in five different groups, i.e. in the MRC, Japan's Mekong Initiative, LMI, Mekong-ROK Cooperation and, in some ways, also in the agreement between China, Laos, Myanmar, and Thailand (i.e. the 'Agreement on Commercial Navigation on Lancang-Mekong River' of 2000). The collaboration is hence excessively scattered among different collaborative groups, whereas it would be more effective and efficient to have fewer yet stronger institutions.

Another common weakness is the character of membership. Although most agreements include all five non-hegemons as members, the most important framework for enhancing cooperation on the water management-MRC - includes only four non-hegemons, while Myanmar is not a full member. When comparing the activeness of riparian states, it is clearly visible that China is the most passive riparian state, as it acts as a full member only in two greater groups-GMS and AMBDC - and has further agreements with Laos, Myanmar, and Thailand as well. Thus, China focuses mainly on bilateral agreements and avoids engaging in multilateral groups.

When answering the research questions of the second section, it is possible to say that the non-hegemonic states are quite active in engaging with different cooperative agreements. However, as many groups coincide in membership as well as in interest areas, their effectiveness is seriously hampered. Instead of spending a myriad of resources on several institutions and organising different summits and meetings, the non-hegemonic states should rather establish with some strong international supporters one broader and stronger cooperative framework dealing actively and on a regular basis with water management. It would also be reasonable to have different working groups, regulations about efficient resolution of differences and tensions between the members, and clear rules - e.g. about data sharing - that all members have to obey. It appears that, in this manner, the non-hegemons could withstand the 
hydro-hegemony of China better and compensate their weakness together as a bloc, instead of having the current scattered network of several smaller groups that do not have sufficient resources and incentives to work actively.

There are several factors that have prevented the non-hegemons from establishing stronger groups. The greatest obstacle seems to be the cleavage between the nonhegemons themselves, caused mainly by their conflicting interests. For instance, it is possible to conclude that the states that are mostly interested in developing hydropower projects - e.g. Laos - or importing hydropower from neighbouring countries - e.g. Thailand - probably do not want to have stricter rules, which might hamper the construction of dams, and hence they would rather avoid the more binding agreements. On the other hand, the countries that are in a vulnerable position and suffer seriously from upstream hydropower projects - e.g. Cambodia and Vietnammay be more interested in those agreements that require stronger commitment and stricter rules.

Additionally, the high dependency on China's investments makes the situation even more complicated, as some riparian states do not want to lose this crucial support and seek a balance between engaging with China and other non-hegemonic states. Also, the fact that the cooperative groups with strong international supporters - e.g. Japan, the USA, South Korea, or India—are too loose, hamper their ability to resist the power asymmetry.

\section{Application of TWINS Approach to the Mekong River Basin}

The final section of the three-level analytical framework examines the relationships in the Mekong River Basin according to the Transboundary Water Interaction Nexus by locating the bilateral interactions in relation to their cooperation (horizontal scale) and conflict (vertical scale) intensities. Therefore, the concluding method of TWINS also utilises as a basis the results of previous sections, i.e. the outcomes of the content analyses of the bargaining and ideational power and counter-hegemonic tools used by non-hegemons, but it includes supplementary elements as well. As a first step, I will use the method for analysing the bilateral interactions between the hydro-hegemon and the non-hegemons separately by looking at the individual national strategies and legislations dealing with water sharing as well as the bilateral agreements regulating the area. The information about the national strategies and legislation will help to understand the relevance of water allocation for each country-i.e. whether the question is politicised, securitised, or handled as a marginal issue - and explain the vertical scale of conflict intensity. It is supplemented with the bilateral agreements that enable to elucidate better the horizontal scale of cooperation intensity. Thereafter, I will examine the relationship between the hydrohegemon and the non-hegemons as a bloc-with the example of the MRC as the 
most important and best institutionalised collaborative group dealing predominantly with water issues - in order to see whether the collaborative measures of nonhegemons have helped them to compensate for their weak position.

The final results of the analytical matrix (Figure 2) indicate that the bilateral relationships between the hydro-hegemonic China and the non-hegemons are diverse, i.e. the groups are located in quite different positions in the table. However, it is also possible to find some similarities. For instance, the relations between China and Thailand, and China and Vietnam are somewhat analogous. There are also some parallels between Cambodia and Laos regarding their interaction with China. On the other hand, the relations between China and Myanmar are in a distant position.

Figure 2 Relations in the Mekong River Basin according to the TWINS approach (compiled by the author)

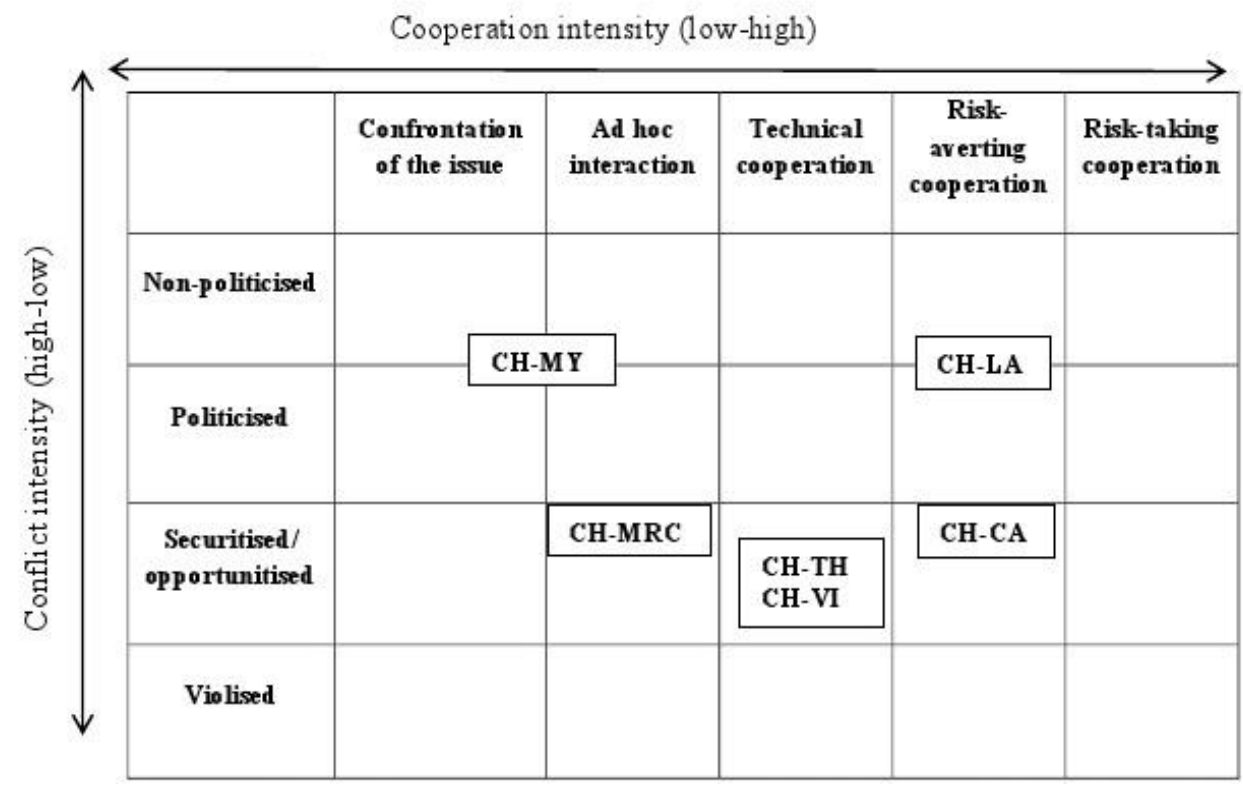

Note: CA - Cambodia, CH - China, LA - Laos, MY - Myanmar, TH - Thailand, VI Vietnam, MRC - Mekong River Commission

The most positive interaction is between China and Laos, as they have neither politicised the issue strongly nor used securitisation. Although both countries concentrate on their national hydropower projects and have quite general regulations about international cooperation on water management, their collaboration is relatively strong due to China's investments in the hydropower projects of Laos and several agreements between the countries, such as the comprehensive strategic cooperative partnership of 2009 that was strengthened in 2011 and 2013 (ANN 2013; MOFA of 
the PRC 2013; People's Daily 2011). In addition, the content analyses of the previous sections demonstrated that Laos and China rather talk about positive accomplishments and do not keenly use the securitisation method. Overall, despite several positive signs, the partnership does not seem to be ideal enough for placing it to the highest category, as the water management is predominantly concentrated on a narrow area, i.e. hydropower development, and thus we can describe it as a riskaverting cooperation. In the conflictive dimension, the relationship could be located between the categories of non-politicisation and politicisation, as the issue of water allocation is included into the political agenda but not handled very intensively or in a detailed way.

Although the relationship between China and Cambodia is usually considered to be strong and cordial, in regard to the water question it is slightly more negative than between China and Laos. The main reason is that the issue is politicised but also partially securitised. For instance, Cambodia has regulated the area with its national laws and strategies rather widely, but there are also examples of securitisation in the media and several protests against China's actions on the local level. On the other hand, the interdependency between states is strong due to China's investments and some recent agreements. For instance, in 2013, the countries signed the Action Plan of the Comprehensive Strategic Partnership of Cooperation that includes, among many other topics, the need for enhancing coordination in water conservancy, and launched the Cambodia-China Intergovernmental Coordination Committee (People's Daily 2013a; 2013b). As a result, the bilateral relationship in the cooperative level could be positioned in the area of risk-averting cooperation, as there are joint actions and goals, such as China's investment and support in Cambodia and the agreement of strategic cooperation. In the conflictive dimension we can see a different picture, as Cambodia has clearly politicised and, by some means, securitised the question of water allocation.

The most negative bilateral relationships are between China and Thailand, and China and Vietnam. The final position in the TWINS matrix is similar for Thailand and Vietnam, because both countries have used politicisation and securitisation in their national strategies. The content analysis of the previous section showed that both countries have also used securitisation relatively often. There have recently also been some agreements with China-e.g. China-Thailand strategic cooperative joint action plans in 2007 and 2012 and the Memorandum of Understanding in 2012 (Royal Thai Government 2007, 2012); China-Vietnam Joint Statement for Future Cooperation in 2000, and the establishment of the Steering Committee on Bilateral Cooperation in 2006 (People's Daily 2000, Thayer 2010) - but due to their general and loose characteristics along with the smaller amount of investments from China in their hydropower projects, the cooperation has been quite technical. One important difference between Thailand and Vietnam could be also seen in terms of their legislation. Whereas Thailand has not very specifically regulated international 
water management, Vietnam has handled the area on the legislative level in a more detailed way. However, Thailand has dedicated a great part of the Eleventh National Economic and Social Development Plan of 2012-16 to the question of water management (Office of the Prime Minister of Thailand 2012) and has used politicisation as well as securitisation techniques. The same can be said about Vietnam, especially when looking at the National Strategy on Climate Change of 2011 (Socialist Republic of Vietnam 2011). As a result, both bilateral relationships could be placed under the category of securitisation in the scale of conflict and under the category of technical cooperation in the cooperative dimension.

The relationship between China and Myanmar is the most neutral interaction and hence quite distant from other bilateral groups. The main reasons for this neutrality are the weak signs of conflict and cooperation on the water issue, as Myanmar has not actively securitised or even politicised the question. For instance, the laws regulating this area are very general and also the cooperation on water management has been rather modest, as neither of the countries demonstrates their concerns and focuses on other topics. The neutrality can be explained with Myanmar's little interest in the river basin, as it currently has enough water resources and is not as vulnerable as the other states. In addition, due to its democratisation process, the government focuses on other issues. Hence, water sharing on the political level is not handled very actively. Therefore, it appears that the issue is quite underdeveloped and non-politicised. However, as there are some minor examples of including the issue into the political agenda of Myanmar, the relationship between China and Myanmar could be located between the categories of non-politicised and politicised in the conflictive dimension of the TWINS matrix. Since the cooperation is not very strong on this matter, but there still are some signs of collaboration in managing water resources, it could be situated between the levels of confrontation of the issue and ad hoc cooperation.

When comparing the bilateral relationships with the interaction between the MRC and China, it is possible to conclude that the MRC has diverse impacts on its member states. On the one hand, Laos and Cambodia have clearly better positions when acting bilaterally with China. However, Thailand and Vietnam are in slightly different situations. This means that although the level of conflict is somewhat lower in the MRC (less securitisation) than in the bilateral relationships, the cooperation is also weaker due to the lack of joint cohesive goals. The refusal of China and Myanmar to join the MRC as full members can also be seen as an example of negative interaction. This situation also requires separate regulations, such as the agreement on the provision of hydrological information on the Mekong River of 2002 or later amendments to this agreement made in 2008 and 2013 (MRC 2013c). However, these steps also indicate that the cooperation is often strengthened after some necessary conditions, such as floods, and can be seen as a spontaneous ad hoc cooperation. Also the antagonistic attitude of the MRC towards China acts as an impediment 
to a stronger relationship, as there are simultaneously positive as well as negative opinions about China's actions.

In brief, it seems that due to different interests among the member states of the MRC - e.g. development of hydropower and interest in China's investments versus environmental protection - the non-hegemonic states are not able to act as a unified and strong force against China. On the conflictive level, we can position the relationship under the category of securitisation. However, the securitisation is not very strongly represented due to the wide spectrum of opinions in the $\mathrm{MRC}$, and thus the relationship is leaning more towards a lower level of conflict. Therefore, this collaborative counter-hegemonic tactic of non-hegemons does not appear to be very successful in resisting the hydro-hegemon and the bilateral relations are often more useful. On the other hand, the power asymmetry in the bilateral relationships is more strongly represented and hence the non-hegemonic states have to comply with the rules of the hydro-hegemony individually and more strongly than within the MRC.

\section{Conclusion}

The three-level analysis used in the research demonstrated that hydro-hegemony plays a great role in the water allocation process. First of all, the hydro-hegemonic order is correlated with the power relations among the six riparian states of the Mekong River Basin, as the hydro-hegemon and non-hegemons of the basin are determined according to four different types of power, a concept developed by Cascão and Zeitoun (2010). Therefore, it was possible to see that China with the highest scores of all four types of power can definitely be regarded as the hydrohegemon of the Mekong River Basin. However, it is also important to highlight that in some subcategories it also experiences deficiencies, such as human capital, availability of water resources, international support, and the usage of ideational power in the media.

Although China as the strongest country in the river basin has also the advantage of being situated in the upstream of the river, the analysis demonstrated that the location is not the main factor determining the power positions among the nonhegemonic states. For instance, Laos could be seen as the most powerful state among the five non-hegemons, despite the fact that it is located below Myanmar. This also means that regardless of its modest indicators on the geographical and economic power, military might, human capital, and size Laos has strengthened its position with the good results in the bargaining and ideational power.

Thailand has similarly balanced its average position in the dimension of geographical and material power with better results in the fields of bargaining and ideational power, especially with its investments in other riparian states and by frequently using the methods of ideational power in the media. In contrast, it was 
possible to see that Myanmar has lost its relatively strong position in the geographical and material power among the riparian states mainly due to low indicators on ideational and bargaining power.

Vietnam and Cambodia as the most downstream states have the most vulnerable and weakest positions in the river basin based on the sum of all types of power. Whereas Vietnam has the lowest score in the geographical power, in regard to material and ideational power it holds quite average positions. Vietnam's best indicator is in bargaining and ideational power, due to its investments in other riparian states and because of the activeness in using the methods of these two types of power. Cambodia has rather low indicators on all four aspects. However, its best position is in ideational power. On the other hand, Cambodia has been one of the most passive riparian countries in using the tools of bargaining power, and has also serious deficiencies concerning geographical and material power.

Although the non-hegemonic states are relatively equal and should thereby have a stronger stimulus to establish collaborative groups for resisting the hydrohegemon, the results of the second section proved the opposite, where the equality of the non-hegemonic states has not prompted them to collaborate effectively. This means that despite the high number of different collaborative groups, the cooperation has been quite weak and fragile in resisting China's hydro-hegemony. The main reasons are the following: a scattered network of many collaborative formations that deal simultaneously with the same topics; the infrequency of meetings; the refusal of both China and Myanmar to join the Mekong River Commission as full members; and the lack of strict regulations that could make it more effective and efficient for all riparian states. The inability to form stronger groups derives mainly from the passiveness, disinterest, or contrasting interests of the riparian states. Also the prevalent tendency of foreign countries to form collaborative groups with the nonhegemons separately but not with other great supporters, and the high dependency of non-hegemons on China are obstructing the cooperation. China as the hydrohegemon and great investor has a crucial role in influencing the actions of nonhegemons, as the latter are not very keen to cooperate with other non-hegemonic states and are afraid to demonstrate their distrust towards China.

The third section of the Transboundary Water Interaction Nexus showed that there are diverse bilateral interactions in the river basin. Whereas the most positive interaction is between China and Laos, the collaboration between China and Cambodia is slightly weaker. The bilateral interactions of China with Thailand and Vietnam are the most negative ones, while the relationship between China and Myanmar is the most neutral one in the river basin. The positive relationship between China and Laos derives mainly from the weak politicisation, China's investments as well as from their mutual agreements. Although the interaction between China and Cambodia is also quite positive, Cambodia's securitisation of water allocation is turning the relationship to a more negative one. On the other hand, in 
the cooperative level, the relations between these two countries are relatively strong, which also demonstrates the importance of the two-dimensional TWINS approach. The relations between China and Thailand, and China and Vietnam are leaning towards a more negative interaction due to the active securitisation in Thailand and Vietnam and the smaller dependency on China's investments. The neutrality of the interaction between China and Myanmar derives from their passivity, while neither of the countries has actively politicised the question nor initiated any remarkable steps for enhancing bilateral cooperation on water management.

The interaction between the hydro-hegemonic China and the bloc of nonhegemons, i.e. the Mekong River Commission, is relatively negative. This means that Laos and Cambodia have definitely better positions by collaborating with China bilaterally. However, Thailand and Vietnam have an ambiguous situation, while the level of cooperation as well as that of conflict is slightly stronger when interacting in a bilateral way with China. Therefore, the joint collaborative action of the nonhegemonic states has not been very successful in resisting the hydro-hegemony and the countries often have even better results when interacting bilaterally with China. Nevertheless, the non-hegemonic states individually have definitely less opportunities to resist the hydro-hegemony and have to comply more with the demands of China. Additionally, the MRC has been successful in implementing some agreements that require hydrological data from China and could be seen as good examples for giving the non-hegemonic states a way of acting together strongly.

The results of the three sections clearly indicate that the phenomenon of hydrohegemony influences transboundary water sharing and the behaviour and activities of the riparian states. As the power asymmetry gives some of the riparian states more dominant positions, it also influences further relations between countries and enables to better understand the tendency and dynamic of the relations in the river basin. For instance, as the weakest country, Cambodia has tried to be active by inducing collaboration on different levels. On the one hand, Cambodia has approached China due to the need for investments, but has also tried to demonstrate its environmentally vulnerable situation in the Mekong River Commission. Moreover, Cambodia has regulated the topic with its legislation and national plans in a detailed way. Vietnam as also being situated in a weak position and has, similarly, tried to regulate the transboundary water allocation on the legislative level and with its national strategies. Thus, Vietnam is quite actively trying to simultaneously enhance cooperation with the international organisations but gradually with China as well. In contrast, Laos that has the best position among the non-hegemons has not politicised the issue of water management strongly and rather tries to cooperate with China and Thailand bilaterally due to its need for investments and also focuses mainly on its national projects. Thailand and Myanmar with middle positions have different approaches. Since Myanmar has relatively little interest in the Mekong River Basin, it has not been very active, but Thailand has tried to approach Laos due to the inter- 
est in importing hydroelectricity from Laos and has also focused on the cooperation with the Mekong River Commission, while worrying about the availability of hydrological data from the upstream states.

Consequently, it is clearly visible that the hydro-hegemony influences water allocation on different levels. On the one hand, we can notice that the hydrohegemonic situation may have an impact on the environmental conditions, as the countries with greater position of power often act in the river basin unilaterally by neglecting the environmental situation or the concerns and needs of other states. This was predominantly demonstrated with the example of concerned voices of the downstream states about the upstream hydropower projects. Moreover, the hydrohegemonic situation influences the relationships between the riparian states, i.e. their behaviour and actions, as the weaker countries often try to find a balance between approaching the hydro-hegemonic state and collaborating with other non-hegemons in order to constrain the hegemonic state. This also means that, due to different behaviour and a wide variety of interests among the non-hegemons, they have not been very successful in resisting the hydro-hegemonic state together. As a result, the protection of the environment and the sustainable use of river water are undermined, compromises are hard to find, and the selfish interests of the states are more salient. Due to hindered multilateral cooperation, the dominating roles of stronger states are also even more visible. The results of the paper thus suggest that hydro-hegemony is an essential aspect in the transboundary water allocation that cannot be overlooked and should definitely be included in the research, as this phenomenon helps to better explain and understand the whole situation and patterns of relationships. 


\section{LIST OF ABBREVIATIONS}

$\begin{array}{ll}\text { AMBDC } & \begin{array}{l}\text { Mekong Basin Development Cooperation } \\ \text { ASEAN }\end{array} \\ \text { GMS } & \text { Grsociation of Southeast Asian Nations } \\ \text { GDP } & \text { Gross Domestic Product } \\ \text { LMI } & \text { Lower Mekong Initiative } \\ \text { MRC } & \text { Mekong River Commission } \\ \text { PPP } & \text { Purchasing Power Parity } \\ \text { PRC } & \text { People's Republic of China } \\ \text { ROK } & \text { Republic of Korea } \\ \text { TWINS } & \text { Transboundary Water Interaction Nexus }\end{array}$




\section{REFERENCES}

Aiken, Michael T. "Beijing's Hydroelectric Policies: Tensions on the Mekong." In Diplomatic Courier, 17 February, 2014, http://www.diplomaticourier.com/blog/2054-beijing-shydroelectric-policies-tensions-on-the-mekong, accessed March 2014

Aquastat. "Total Renewable Water Resources." Food and Agriculture Organization of the United Nations, 2012, http://www.fao.org/nr/water/aquastat/data/query/results.html, accessed February 2014

Asia News Network (ANN). "Laos, China Agree to Deepen Relations.” In Asia News Network, 1 October, 2013, http://www.asianewsnet.net/Laos-China-agree-to-deepen-relations52294.html, accessed April 2014

Asian Development Bank (ADB). Key Indicators for Asia and the Pacific 2013. Mandaluyong City: ADB, 2013

Brochmann, Marit and Nils Petter Gleditsch. "Shared Rivers and Conflict: A Reconsideration." In Political Geography, 31, 2012, pp. 519-527

Buzan, Barry and Lene Hansen. The Evolution of International Security Studies. Cambridge: Cambridge University Press, 2009

Buzan, Barry, Ole Wæver, and Jaap de Wilde. Security: A New Framework for Analysis. Boulder: Lynne Rienner Publishers, 1998

Cartin, Megan, Rebecca Welling, Ganesh Pangare, and Tawatchai Rattansorn. Mekong River Basin: Mobilising Grassroots Engagement and Facilitating High-level Dialogue for Transboundary Water Management. Gland: International Union for Conservation of Nature, 2012

Cascão, Ana Elisa. "Hydro-Hegemony and Counter Hydro-Hegemony in the Nile River Basin." London Water Research Group: Second International Workshop on Hydro-Hegemony, May 2006, http://lwrg.org/hydro-hegemony-2006.html, accessed January 2014

Cascão, Ana Elisa and Mark Zeitoun. "Changing Nature of Bargaining Power in the Hydropolitical Relations in the Nile River Basin." In Transboundary Water Management: Principles and Practice, edited by Anton Earle, Anders Jägerskog, and Joakim Öjendal. London: Earthscan, 2010a, pp. 187-191

Cascão, Ana Elisa and Mark Zeitoun. "Power, Hegemony and Critical Hydropolitics." In Transboundary Water Management: Principles and Practice, edited by Anton Earle, Anders Jägerskog, and Joakim Öjendal. London: Earthscan, 2010b, pp. 27-42

Chellaney, Brahma. “China's Hydro-Hegemony.” In The New York Times, 7 February 2013, http://www.nytimes.com/2013/02/08/opinion/global/chinas-hydro-hegemony.html?_r=1\&, accessed February 2014

Chomchai, Prachoom. "Public Participation in Watershed Management in Theory and Practice: A Mekong River Basin Perspective.” In Public Participation in the Governance of International Freshwater Resources, edited by Carl Bruch, Libor Jansky, Mikiyasu Nakayama, and Kazimierz A. Salewicz. New York: United Nations University Press, 2005, pp. 139-155

Collins, Alan. Security and Southeast Asia: Domestic, Regional, and Global Issues. Boulder: Lynne Rienner Publishers, 2003

Cronin, Richard P. "Hydropower Dams on the Mekong: Old Dreams, New Dangers." In Asia Policy, 16, 2013, pp. 32-38

Cronin, Richard P. and Timothy Hamlin. Mekong Tipping Point: Hydropower Dams, Human Security and Regional Stability. Washington, DC: The Henry L. Stimson Center, 2010

Cronin, Richard P. and Timothy Hamlin. Mekong Turning Point: Shared River for a Shared Future. Washington: The Henry L. Stimson Center, 2012

Dahl, Robert A. “The Concept of Power.” In Behavioral Science, 2/3, 1957, pp. 201-215 
Daoudy, Marwa. "Asymmetric Power: Negotiating Water in the Euphrates and Tigris." In International Negotiation, 14, 2009, pp. 359-389

David, Sen. "Locals Air Criticisms of Controversial Lao Dam.” In The Phnom Penh Post, 17 November 2013, http://www.phnompenhpost.com/national/locals-air-criticisms-controversiallao-dam, accessed March 2014

DeSombre, Elizabeth R. "Tuna Fishing and Common Pool Resources.” In Anarchy and the Environment: The International Relations of Common Pool Resources, edited by Samuel J. Barkin and George E. Shambaugh. Albany: State University of New York Press, 1999, pp. 5169

Deudney, Daniel. "The Case Against Linking Environmental Degradation and National Security." In Millenium, 19, 1990, pp. 461-476

Dinar, Ariel, Shlomi Dinar, Stephen McCaffrey, and Daene McKinney. Bridges Over Water: Understanding Transboundary Water Conflict, Negotiation and Cooperation. Singapore: World Scientific Publishing, 2007

Elhance, Arun P. Hydropolitics in the Third World: Conflict and Cooperation in International River Basins. Washington: United States Institute of Peace, 1999

Fawthrop, Tom. "Lao Dam Project Raises Mekong Fear.” In Asia Times Online, 27 November 2013, http://www.atimes.com/atimes/Southeast_Asia/SEA-01-271113.html, accessed March 2014

Gassert, Francis, Paul Reig, Tianyi Luo, and Andrew Maddocks. Aqueduct Country and River Basin Rankings: A Weighted Aggregation of Spatially Distinct Hydrological Indicators. Washington: World Resources Institute, 2013

Haacke, Jürgen. "South-East Asia's International Relations and Security Perspectives." In East and South East Asia: International Relations and Security Perspectives, edited by Andrew T. H.Tan. London and New York: Routledge, 2013, pp. 154-166

Hauge, Wenche and Tanja Ellingsen. "Beyond Environmental Scarcity: Causal Pathways to Conflict." In Journal of Peace Research, 35/3, 1998, pp. 299-317

Hinton, Peter. "Where Nothing Is as It Seems: Between Southeast China and Mainland Southeast Asia in the 'Post-Socialist' Era." In Where China Meets Southeast Asia: Social and Cultural Change in the Border Regions, edited by Christopher Hutton, Grant Evans, and Kuah Khun Eng. New York: St. Martin's Press, 2000, pp. 7-27

Homer-Dixon, Thomas F. Environment, Scarcity, and Violence. Princeton: Princeton University Press, 2010

International Centre for Environmental Management (ICEM). Strategic Environmental Assessment of Hydropower on the Mekong Mainstream. Hanoi: ICEM, 2010

International Institute of Strategic Studies (IISS). The Military Balance 2015. London: Routledge, 2015

International Rivers. "Spreadsheet of Major Dams in China." 2013, www.internationalrivers.org/ resources/spreadsheet-of-major-dams-in-china-7743, accessed February 2014

Itäranta, Emmi. Memory of Water: A Novel. New York: Harper Collins Publisher, 2014

Keskinen, Marko, Katri Mehtonen, and Olli Varis. "Transboundary Cooperation Vs. Internal Ambitions: The Role of China and Cambodia in the Mekong Region." In International Water Security: Domestic Threats and Opportunities, edited by Nevelina I. Pachova, Mikiyasu Nakayama, and Libor Jansky. Tokyo: United Nations University Press, 2008

Kirby, Mac, Chayanis Krittasudthacheewa, Mohammed Mainuddin, Eric Kemp-Benedict, Chris Swartz, and Elnora de la Rosa. "The Mekong: A Diverse Basin Facing the Tensions of Development." In Water International, 35/5, 2010, pp. 573-593 
Leibo, Steven A. The World Today Series 2012: East and Southeast Asia. Forty-Fifth Edition. Lanham: Stryker-Post Publications, 2012

Li, Xinlin. "Hydropower in the Mekong River Basin: A Balancing Test." In Environmental Claims Journal, 24/1, 2012, pp. 51-69

London Water Research Group (LWRG). “About Us.” 2014, http://lwrg.org/about-us.html, accessed May 2014

Magee, Darrin. "China Fails to Build Trust with Mekong Neighbours." In The Third Pole, 24 July 2013, http://www.thethirdpole.net/china-fails-to-build-trust-with-mekong-neighbours/, accessed March 2014

Mekong River Commission (MRC). Agreement on the Cooperation for the Sustainable Development of the Mekong River Basin. Chieng Rai: MRC, 5 April, 1995

Mekong River Commission (MRC). "First MRC Summit.” Hua Hin, Thailand, 5 April 2010, http://www.mrcmekong.org/news-and-events/speeches/first-mrc-summit-4/, accessed February 2014

Mekong River Commission (MRC). Annual Report 2010. Phnom Penh: MRC, 2011a

Mekong River Commission (MRC). Planning Atlas of the Lower Mekong River Basin. Phnom Penh: MRC, 2011b

Mekong River Commission (MRC). Report of 16th Dialogue Meeting. Vientiane: MRC, 29 August, 2011c

Mekong River Commission (MRC). Mekong River Commission Operating Expenses Budget. Hanoi: MRC, 2012

Mekong River Commission (MRC). Mekong Basin Planning: The Basin Development Plan Story. PhnomPenh and Vientiane: Mekong River Commission, 2013a

Mekong River Commission (MRC). "Mekong River Commission and China Boost Water Data Exchange." 2013b, http://www.mrcmekong.org/news-and-events/news/mekong-rivercommission-and-china-boost-water-data-exchange/, accessed March 2014

Mekong River Commission (MRC). "Upstream Partners.” 2013c, http://www.mrcmekong.org/ about-the-mrc/upstream-partners-2/, accessed February 2014

Menniken, Timo. "China's Performance in International Resource Politics: Lessons from the Mekong.” In Contemporary Southeast Asia, 29/1, 2007, pp. 97-120

Ministry of Foreign Affairs (MOFA) of the People's Republic of China (PRC). "Chinese Consulate-General in Luang Prabang Opens.” 2013, http://www.mfa.gov.cn/eng/wjb/zwjg/zwbd/ t1114409.shtml, accessed April 2014

Mirumachi, Naho and John Anthony Allan. "Revisiting Transboundary Water Governance: Power, Conflict, Cooperation and the Political Economy." In CAIWA Conference Paper, 2007, http://www.newater.uni-osnabrueck.de/caiwa/data/papers\%20session/F3/CAIWA-FullPaperMirumachiAllan25Oct07submitted2.pdf, accessed January 2014

Mitchell, Ronald B. International Politics and the Environment. London: Sage, 2010

Nye, Joseph S. The Future of Power. New York: Public Affairs TM, 2011

Office of the Prime Minister of Thailand. The Eleventh National Economic and Social Development Plan of 2012-2016. Bangkok: National Economic and Social Development Board, 2012

Onishi, Kayo. "Interstate Negotiation Mechanisms for Cooperation in the Mekong River Basin." In Water International, 32/4, 2007, pp. 524-537

Pacific Institute. "Water Conflict Chronology List." 2012, http://www2.worldwater.org/conflict/ list/, accessed March 2014

People's Daily. “China, Viet Nam Sign Joint Statement for Future Cooperation.” 26 December 2000, http://english.peopledaily.com.cn/english/200012/25/eng20001225_58777.html, accessed April 2014 
People's Daily. “Laos, China pledge to strengthen ties.” 17 February 2011, http://english.peopledaily.com.cn/90001/90776/90883/7291093.html, accessed April 2014

People's Daily. "Cambodia-China meeting to deepen bilateral ties, cooperation." 31 December 2013a, http://english.peopledaily.com.cn/90883/8500726.html, accessed April 2014

People's Daily. "Full text of China-Cambodia joint press communique." 9 April 2013b, http://english.people.com.cn/90883/8200926.html, accessed April 2014

Pomeranz, Kenneth. “Asia's Unstable Water Tower: The Politics, Economics, and Ecology of Himalayan Water Projects.” In Asia Policy, 16, 2013, pp. 4-10

Reporters Without Borders. "Biggest Rises and Falls in the 2014 World Press Freedom Index." 2014, http://rsf.org/index2014/en-index2014.php, accessed March 2014

Royal Thai Government. "China, Thailand Sign Deals to Enhance Strategic Co-op.” 2007, http://www.thaigov.go.th/en/news-room/item/56554-china-thailand-sign-deals-to-enhancestrategic-co-op.html, accessed April 2014

Royal Thai Government. "Thai and Chinese Prime Minister Witnessed the Signing of 8 Strategic Cooperation Agreements Between the Two Countries.” 2012, http://www.thaigov.go.th/en/ news-room/item/69256-thai-and-chinese-prime-minister-witnessed-the-signing-of-8-strategiccooperation-agreements-between-the-two-countries-19/4/2012.html, accessed April 2014

Schmeier, Susanne. "Regional Cooperation Efforts in the Mekong River Basin: Mitigating RiverRelated Security Threats and Promoting Regional Development." In Austrian Journal for Southeast Asian Studies, 2/2, 2009, pp. 28-52

Schulze, Sabine and Susanne Schmeier. "Governing Environmental Change in International River Basins: The Role of River Basin Organizations." In International Journal of River Basin Management, 10/3, 2012, pp. 229-244

Sinha, Uttam Kumar. “Examining China's Hydro-Behaviour: Peaceful or Assertive?” In Strategic Analysis, 36/1, 2012, pp. 41-56

Socialist Republic of Vietnam. "National Strategy on Climate Change." 2011, http://www.chinhphu.vn/portal/page/portal/English/strategies/strategiesdetails?categoryId=30 \&articleId=10051283, accessed April 2014

Stockholm International Peace Research Institute (SIPRI). "The SIPRI Military Expenditure Database.” 2014, http://www.sipri.org/research/armaments/milex/milex_database, accessed May 2015

Thayer, Carlyle A. "Vietnam and Rising China: The Structural Dynamics of Mature Asymmetry." In Southeast Asian Affairs, 2010, pp. 392-409

Thim, Ly. Planning the Lower Mekong Basin: Social Intervention of the Se San River. Berlin: LIT, 2010

United Nations (UN). Statistical Yearbook for Asia and the Pacific 2012: Country Profiles. Bangkok: United Nations Economic and Social Commission for Asia and the Pacific, 2012

United Nations Environment Programme (UNEP). Mekong River, GIWA Regional Assessment 55. Kalmar: University of Kalmar, 2006

Victor, David G.; Kal Raustiala, and Eugene B. Skolnikoff, eds. The Implementation and Effectiveness of International Environmental Commitments: Theory and Practice. Laxenburg: International Institute for Applied System Analysis, 1998

Warner, Jeroen. Plugging the GAP: Working with Buzan: The Ilisu Dam as a Security Issue. (Occasional Paper No 67; SOAS Water Issues Study Group). London: School of Oriental and Asian Studies at University College London, 2004

Warner, Jeroen F. and Neda Zawahri. "Hegemony and Asymmetry: Multiple-chessboard Games on Transboundary Rivers." In International Environmental Agreements, 12/3, 2012, pp. 215229 
Warner, Jeroen F. and Mark Zeitoun. "International Relations Theory and Water Do Mix: A Response to Furlong's Troubled Waters, Hydro-hegemony and International Water Relations." In Political Geography, 27, 2008, pp. 802-810

Wolf, Aaron T. and Joshua T. Newton. "Case Studies of Transboundary Dispute Resolution." In Managing and Transforming Water Conflicts, edited by Delli J. Priscoli and Aaron T. Wolf. Cambridge: Cambridge University Press, 2008, pp. 216-222

Wolf, Aaron T., Annika Kramer, Alexander Carius, and Geoffrey D. Dabelko. "Water Can Be a Pathway to Peace, Not War." In Navigating Peace, 1, 2006, pp. 1-6

World Bank. "Fixed Broadband Internet Subscribers (per 100 People)." 2012a, http://data.worldbank.org/indicator/IT.NET.BBND.P2, accessed May 2014

World Bank. "Labor Force Participation Rate, Total (\% of Total Population Ages 15-64) (Modeled ILO Estimate).” 2012b, http://data.worldbank.org/indicator/SL.TLF.ACTI.ZS, accessed May 2014

World Bank. "Mobile Cellular Subscriptions (per 100 People)." 2012c, http://data.worldbank.org/indicator/IT.CEL.SETS.P2, accessed May 2014

World Bank. "Unemployment, Total (\% of Total Labor Force) (Modeled ILO Estimate)." 2012d, http://data.worldbank.org/indicator/SL.UEM.TOTL.ZS, accessed May 2014

World Bank. "Unemployment, Total (\% of Total Labor Force) (Modeled ILO Estimate)." 2012e, http://data.worldbank.org/indicator/SL.UEM.TOTL.ZS, accessed May 2014

World Bank. "School Enrolment, Tertiary (\% Gross)." 2013, http://data.worldbank.org/indicator/SE.TER.ENRR, accessed February 2014

World Bank. "Land Area (sq. km)." 2014, http://data.worldbank.org/indicator/AG.LND.TOTL.K2, accessed May 2015

Zeitoun, Mark. "Violations, Opportunities and Power along the Jordan River: Security Studies Theory Applied to Water Conflict." In Water Resources in the Middle East: Israel-Palestinian Water Issues From Conflict to Cooperation, edited by Hillel Shuval and Hassan Dweik. Berlin: Springer, 2007, pp. 213-224

Zeitoun, Mark. Power and Water in the Middle East: The Hidden Politics of the PalestinianIsraeli Water Conflict. London: I. B. Tauris, 2008

Zeitoun, Mark. "The Political Economy of Water Demand Management in Yemen and Jordan: A Synthesis of Findings." In Water Demand Management Research Series: Working Paper No. 5, October 2009, Regional Water Demand Initiative in the Middle East and North Africa, https://www.uea.ac.uk/polopoly_fs/1.147019!Zeitoun_PE_WDM_Yemen_and_Jordan.pdf, accessed February 2014

Zeitoun, Mark and Tony Allan. "Applying Hegemony and Power Theory to Transboundary Water Analysis." In Water Policy, 10/S2, 2008, pp. 3-12

Zeitoun, Mark and Naho Mirumachi. "Transboundary Water Interaction I: Reconsidering Conflict and Cooperation.” In International Environmental Agreements, 8/4, 2008, pp. 297-316 